\title{
PROFIL PENGGUNAAN ANTIBIOTIK PADA PASIEN ISPA DI BEBERAPA PUSKESMAS KOTA SAMARINDA
}

\author{
Rizki Khairunnisa*, Hajrah, Rolan Rusli \\ Laboratorium Penelitian dan Pengembangan FARMAKA TROPIS \\ Fakultas Farmasi Universitas Mulawarman Samarinda Kalimantan Timur \\ *email:icirizki@gmail.com
}

\begin{abstract}
ABSTRAK
Infeksi Saluran Pernapasan Akut (ISPA) adalah penyakit saluran pernapasan atas atau bawah yang berlangsung hingga 14 hari dan biasanya menular. Infeksi saluran pernapasan akut (ISPA) merupakan penyakit dengan prevalensi yang tinggi. Sebagian besar ISPA yang terjadi disebabkan oleh virus dan tidak memerlukan antibiotik. Penelitian ini bertujuan untuk mengetahui karakteristik serta pola penggunaan antibiotik pada pasien ISPA. Penelitian ini di lakukan secara retrospektif dengan mengambil data dari rekam medik pasien penderita ISPA sebanyak 221 pasien. Karakteristik pasien berdasarkan jenis kelamin diperoleh persentasi pasien laki-laki dan perempuan berturut-turut $(45,25 \%)$ dan $(54,75 \%)$. Pasien penderita ISPA paling banyak terjadi di usia 36-45 tahun $(29,41 \%), 18-25$ tahun $(28,96 \%)$, 26-35 tahun $(25,34 \%)$ dan 46-55 tahun $(19,29 \%)$. Hasil diagnosa dokter meliputi influenza oleh virus $(4,22 \%)$, influenza (virus tidak teridentifikasi) $(18,99 \%)$, faringitis akut $(45,15 \%)$, tonsillitis akut $(24,48 \%)$, nesofaringitis akut $(4,22 \%)$, bronkitis akut $(0,42 \%)$, laringitis akut $(0,42 \%)$, ISPA tidak dispesifikasi $(1,26 \%)$ dan sinusitis akut $(0,84 \%)$. Antibiotik yang digunakan adalah amoksisilin $500 \mathrm{mg}$ (83,71\%), amoksisilin $250 \mathrm{mg}$ (0,45\%), kotrimoksazol $480 \mathrm{mg}(8,15 \%)$, kloramfenikol $250 \mathrm{mg}(0,45 \%)$, siprofloksasin $500 \mathrm{mg}$ $(4,07 \%)$, sefadroksil $500 \mathrm{mg}(2,72 \%)$ dan eritromisin $250 \mathrm{mg}(0,90 \%)$. Berdasarkan hasil penelitian yang diperoleh maka dapat disimpulkan bahwa penderita ISPA lebih banyak terjadi pada perempuan dan antibiotik yang banyak digunakan sebagai terapi ISPA adalah amoksisilin $500 \mathrm{mg}$.
\end{abstract}

Kata kunci : Antibiotik, ISPA, amoksisilin

\section{ABSTRACT}

Acute Respiratory Infections (ARI) is a respiratory disease and can be classified as upper respiratory track infection and lower respiratory track infection. This disease usually contagious and can last up until 14 days. Acute respiratory infection (ARI) is a disease is a high prevalence. Most of ARI is caused by viruses and do not require antibiotics. This study aims was to determine the characteristics and patterns of antibiotic use in patients with ARI. This study was done retrospectively by taking data from medical records of 221 ARI patients. Characteristic of patient was $45.25 \%$ male and $54.75 \%$ female. The most prevalent of patients with ARI was 36-45 years (29.41\%), 18-25 years (28.96\%), 26-35 years $(25.34 \%)$ and 46-55 years (19,29\%). The doctor diagnosis was influenza caused virus $(4.22 \%)$, influenza (virus not identified) (18.99\%), acute pharyngitis $(45.15 \%)$, acute tonsillitis (24.48\%), acute nesofaringitis $(4,22 \%)$, acute bronchitis $(0.42 \%)$, acute laryngitis $(0.42 \%)$, ARI unspecified (1.26\%) and acute sinusitis (0.84\%). The antibiotics used were amoxicillin $500 \mathrm{mg}$ (83.71\%), amoxicillin $250 \mathrm{mg}$ (0.45\%), cotrimoxazole $480 \mathrm{mg}$ (8.15\%), chloramphenicol $250 \mathrm{mg}(0.45 \%)$, ciprofloxacin $500 \mathrm{mg}(4.07 \%)$, cefadroxil $500 \mathrm{mg}$ 
(2.72\%) and erythromycin $250 \mathrm{mg}(0.90 \%)$. It can be concluded that ARI occurs more frequently in women and amoxicillin $500 \mathrm{mg}$ as antibiotics are widely used in a ARI therapeutic.

Keywords: Antibiotics, ISPA, amoxicillin

\section{PENDAHULUAN}

Infeksi pada saluran napas merupakan penyakit yang umum terjadi pada masyarakat. Secara umum penyebab dari infeksi saluran napas adalah berbagai mikroorganisme, namun yang terbanyak akibat infeksi virus dan bakteri. Faktor-faktor yang mempengaruhi penyebaran infeksi saluran nafas antara lain faktor lingkungan, perilaku masyarakat yang kurang baik terhadap kesehatan diri maupun publik, serta rendahnya gizi.

Infeksi saluran pernapasan akut (ISPA) merupakan penyakit dengan prevalensi yang tinggi khususnya di Kota Samarinda. Infeksi pada saluran pernapasan atas adalah kondisi akut yang paling sering didapati di pelayanan kesehatan dasar (puskesmas). Sebagian besar ISPA yang terjadi disebabkan oleh virus dan tidak memerlukan antibiotik. Sebuah studi di Amerika Serikat menemukan bahwa lebih dari setengah kasus ISPA pada usia dewasa diberikan antibiotik spektrum luas pada resep mereka (setelah dilakukan kontrol untuk diagnosis dan komorbiditas).

Antibiotik adalah agen yang digunakan untuk mencegah dan mengobati suatu infeksi karena bakteri. Akan tetapi, istilah antibiotik sebenarnya mengacu pada zat kimia yang dihasilkan oleh satu macam organisme, terutama fungi, yang menghambat pertumbuhan atau membunuh organisme yang lain. Berdasarkan mekanisme kerjanya terhadap bakteri, antibiotik dikelompokkan menjadi inhibitor sintesis dinding sel bakteri (golongan beta laktam seperti penisilin, sefalosporin, karbapenem, monobaktam dan antibiotik lainnya seperti vancomysin, basitrasin, fosfomysin dan daptomysin), inhibitor sintesis protein bakteri (aminoglikosida, makrolida, tetrasiklin), menghambat sintesis folat (sulfonamida dan trimetoprim), mengubah permeabilitas membran sel (polimiksin, amfoterisin B, gramisidin, nistatin, kolistin), mengganggu sintesis DNA (metronidasol, kinolon, novobiosin) dan mengganggu sintesis RNA (rifampisin).

Tingginya angka kejadian infeksi menyebabkan tidak terhindarkannya penggunaan antibiotik sebagai salah satu obat anti infeksi. Hal tersebut meningkatkan peluang terjadinya insiden penggunaan antibiotik yang tidak rasional yang dapat menyebabkan kejadian resistensi antibiotik. Resistensi antibiotik telah menjadi perhatian masyarakat di seluruh belahan dunia, hal tersebut memerlukan kesadaran bersama akan adanya hubungan antara tingkat resistensi antibiotik dengan pola penggunaan antibiotik. Informasi mengenai pola penggunaan antibiotik dapat digunakan sebagai alat deteksi dini adanya ketidakrasionalan dan sebagai sumber informasi dalam pengendalian resistensi antibiotik.

Berdasarkan hal tersebut maka perlu dilakukan penelitian mengenai pola penggunaan antibiotik pada pasien ISPA di beberapa Puskesmas Kota Samarinda. Tujuan dari penelitian ini adalah mengetahui karakteristik pasien serta pola penggunaan antibiotik pasien ISPA di beberapa Puskesmas Kota Samarinda

\section{METODE PENELITIAN}

Penelitian ini dilakukan secara retrospektif dengan mengambil data dari rekam medik pasien penderita ISPA di beberapa Puskesmas di Kota Samarinda pada periode September sampai Oktober 2016. Data dikumpulkan berdasarkan kriteria inklusi yaitu responden dengan diagnosa ISPA, usia >18 tahun, menggunakan antibiotik dan pasien memiliki data rekam medik yang lengkap. Data yang ada dianalisis secara deskriptif. 


\section{HASIL DAN PEMBAHASAN}

Penelitian ini dilakukan di beberapa Puskesmas Kota Samarinda dengan mengumpulkan data rekam medik pasien ISPA. Sampel yang digunakan yaitu pasien penderita ISPA yang mendapatkan antibiotik. Jumlah pasien yang didapatkan yaitu sebanyak 221 pasien. Karakteristik usia pasien penderita ISPA dapat dilihat pada tabel 1. Karakteristik pasien ISPA usia tertinggi adalah usia 36-45 tahun sebanyak 29,41\%.

Tabel 1. Distribusi usia pasien penderita ISPA dibeberapa puskesmas Kota Samarinda

\begin{tabular}{ccc}
\hline Usia (tahun) & $\begin{array}{c}\text { Jumlah Pasien } \\
\text { (Orang) }\end{array}$ & Persentase (\%) \\
\hline $18-25$ & 64 & 28,96 \\
$26-35$ & 56 & 25,34 \\
$36-45$ & 65 & 29,41 \\
$46-55$ & 36 & 19,29 \\
\hline Total & $\mathbf{2 2 1}$ & $\mathbf{1 0 0}$ \\
\hline
\end{tabular}

Hasil yang didapatkan tidak memperlihatkan perbedaan yang signifikan karena pada usia ini merupakan usia produktif dimana banyak orang melakukan aktivitas di luar rumah sehingga mudah terkena ISPA dikarenakan pencemaran udara seperti yang berasal dari asap kendaraan ataupun asap rokok.

Karakteristik pasien berdasarkan jenis kelamin diperoleh persentasi pasien laki-laki dan perempuan berturut-turut $(45,25 \%)$ dan $(54,75 \%)$.

Tabel 2. Distribusi jenis kelamin penderita ISPA dibeberapa Puskesmas Kota Samarinda

\begin{tabular}{ccc}
\hline Jenis Kelamin & $\begin{array}{c}\text { Jumlah Pasien } \\
\text { (Orang) }\end{array}$ & Persentase (\%) \\
\hline Laki-laki & 100 & 45,25 \\
Perempuan & 121 & 54,75 \\
\hline Total & $\mathbf{2 2 1}$ & $\mathbf{1 0 0}$ \\
\hline
\end{tabular}

Dari data pasien pada tabel 2, terlihat bahwa jenis kelamin perempuan mengalami ISPA paling banyak dibandingkan laki-laki. Tidak ada hubungan yang bermakna antara jenis kelamin dengan kejadian ISPA. Belum ada penelitian lebih lanjut mengenai hal ini, kemungkinan dikarenakan perempuan memiliki aktivitas yang banyak dilingkungan rumah dan sekitarnya yang terdapat pencemaran udara dari penggunaan biomasa untuk memasak dan asap rokok.

Karakteristik pasien berdasarkan diagnosa dokter diperoleh presentasi influenza oleh virus $(4,22 \%)$, influenza (virus tidak teridentifikasi) $(18,99 \%)$, faringitis akut $(45,15 \%)$, tonsillitis akut $(24,48 \%)$, nesofaringitis akut $(4,22 \%)$, bronkitis akut $(0,42 \%)$, laringitis akut $(0,42 \%)$, ISPA tidak dispesifikasi $(1,26 \%)$ dan sinusitis akut $(0,84 \%)$. Persentasi tertinggi yaitu pasien dengan diagnosa faringitis akut $(45,15 \%)$.

Dari tabel 3 terlihat bahwa faringitis merpakan penyakit yang paling banyak terjadi. Hal ini dikarenakan iklim panas pada kota Samarinda sehingga masyarakat cenderung 
memilih minuman yang dingin. Keadaan seperti mengkonsumsi minuman dingin secara berkala dapat mengiritasi mukosa faring dan esofagus yang meningkatkan terjadinya inflamasi kronik.

Tabel 3. Distribusi pasien berdasarkan diagnosa dokter

\begin{tabular}{ccc}
\hline diagnosa & $\begin{array}{c}\text { Jumlah Pasien } \\
\text { (Orang) }\end{array}$ & Persentase (\%) \\
\hline Influenza oleh virus & 10 & 4,22 \\
Influenza (virus tidak & 45 & 18,99 \\
teridentifikas) & 107 & 45,15 \\
Faringitis akut & 58 & 24,48 \\
Tonsilitis akut & 1 & 0,42 \\
Laringitis akut & 3 & 1,26 \\
ISPA tidak dispesifikasi & 1 & 0,42 \\
Bronkitis akut & 10 & 4,22 \\
Nesofaringitis akut & 2 & 0,84 \\
Sinusitis akut & $\mathbf{2 3 7}$ & $\mathbf{1 0 0}$
\end{tabular}

Faringitis akut yaitu salah satu penyakit yang ditandai dengan adanya infeksi yang biasanya terjadi pada saluran nafas bagian atas dan merupakan suatu gejala infeksi lokal yang spesifik di bagian faring atau tenggorokan Biasa juga disebut sebagai radang tenggorokan. Gangguan ini disebabkan oleh infeksi bakteri atau virus. Banyak penyebab yang dapat membuat penyakit ini datang, dari mulai merokok, memiliki riwayat penyakit sinus, debu dan polusi. Bakteri yang biasa menyerang penyakit ini adalah Streptococcus pharyngitis.

Tabel 4. Distribusi Jenis dan Dosis Antibiotik

\begin{tabular}{ccc}
\hline Jenis antibiotik & $\begin{array}{c}\text { Jumlah Pasien } \\
\text { (Orang) }\end{array}$ & Persentase (\%) \\
\hline Amoksisilin 500 mg & 185 & 83,71 \\
Amoksisilin 250 mg & 1 & 0,45 \\
Kotrimoksazol 480mg & 18 & 8,15 \\
Kloramfenikol 250mg & 1 & 0,45 \\
Siprofloksasin 500 mg & 9 & 4,07 \\
Sefadroksil 500 mg & 6 & 2,72 \\
Eritromisin 250 mg & 1 & 0,45 \\
\hline Total & $\mathbf{2 2 1}$ & $\mathbf{1 0 0}$ \\
\hline
\end{tabular}

Penggunaan antibiotik 38,63\% hal ini melebihi dari angka rasional yang telah ditetapkan yaitu 20\%. Penggunaan suatu obat dikatakan tidak rasional jika kemungkinan dampak negatif yang diterima oleh pasien lebih besar dibanding manfaatnya. Dampak 
negatif di sini dapat berupa: a. Dampak klinik (misalnya terjadinya efek samping dan resistensi kuman), b. Dampak ekonomi (biaya tidak terjangkau).

Antibiotik paling banyak digunakan yaitu golongan penisilin. Antibiotik ini merupakan jenis antibiotik spektrum luas yang memiliki aktifitas baik terhadap bakteri Gram positif maupun Gram negative. Amoksisilin sebagai antibiotik golongan beta laktam spektrum luas yang umum digunakan untuk infeksi pernafasan. Efek samping yang umum terjadi pada antibiotik beta laktam seperti amoksisilin dan sefadroksil adalah kemerahan, diare dan peningkatan nilai SGOT/SGPT, selain itu kedua obat ini memiliki potensi alergi yang tinggi sehingga penggunaannya harus berhati-hati untuk menghindari efek yang tidak diiinginkan.

Begitu juga penggunaan antibiotik untuk ISPA non pneumonia sebesar 38,63\% hal ini melebihi dari angka yang telah ditetapkan yaitu $20 \%$.

Tabel 5.

Frekuensi pemberian antibiotik yang terbanyak yaitu amoksisilin $3 \times 1$ disajikan pada

Tabel 5. Distribusi frekuensi pemberian

\begin{tabular}{ccc}
\hline Frekuensi & $\begin{array}{c}\text { Jumlah Pasien } \\
\text { (Orang) }\end{array}$ & Persentase (\%) \\
\hline Amoksisilin $3 \times 1$ & 178 & 80,55 \\
Amoksisilin $2 \times 1$ & 8 & 3,62 \\
Kotrimoksazol $2 \times 2$ & 18 & 8,14 \\
Kloramfenikol $4 \times 1$ & 1 & 0,45 \\
Siprofloksasin $2 \times 1$ & 9 & 4,07 \\
Sefadroksil $2 \times 1$ & 6 & 2,72 \\
Eritromisin $4 \times 1$ & 1 & 0,45 \\
\hline Total & $\mathbf{2 2 1}$ & $\mathbf{1 0 0}$
\end{tabular}

Frekuensi pemberian antibiotik yang terbanyak yaitu amoksisislin $3 \times 1$. Waktu pemberian obat juga dipengaruhi oleh frekuensi penggunaan obat. Ketika obat memiliki frekuensi $3 \mathrm{x}$ sehari maka untuk mendapatkan hasil yang optimal $(24 \mathrm{jam} / 3=8 \mathrm{jam})$ obat diminum tiap 8 jam. Obat memiliki indeks terapi/dosis didalam tubuh yang memberikan efek terapi. Ketika obat masuk dalam indeks terapi maka akan memberikan efek terapi. Bila kadar obat didalam tubuh dibawah indeks terapi maka efek terapi akan hilang/tidak berefek. Sedangkan ketika kadar obat didalam tubuh diatas indeks terapi maka akan terjadi over dosis. 6.

Lama pemberian antibiotik yang terbanyak yaitu selama 5 hari, disajikan pada tabel

Tabel 6. Distribusi lama pemberian

\begin{tabular}{ccc}
\hline Lama Pemberian (hari) & $\begin{array}{c}\text { Jumlah Pasien } \\
\text { (Orang) }\end{array}$ & Persentase (\%) \\
\hline 3 & 51 & 23,08 \\
4 & 4 & 1,81 \\
5 & 161 & 72,85 \\
6 & 4 & 1,81 \\
7 & 1 & 0,45 \\
\hline Total & $\mathbf{2 2 1}$ & $\mathbf{1 0 0}$ \\
\hline
\end{tabular}


Lama pemerian antibiotik terbanyak yaitu selama 3-5 hari. Lama penggunaan antibiotika dikelompokkan berdasarkan studi literatur yang dilakukan dimana lama pemberian antibiotik untuk sebagian besar penyakit infeksi adalah selama 3-7 hari [9]. Penggunaan antibiotik yang tidak tepat merupakan masalah penting di seluruh dunia, penggunaan antibiotik pada infeksi pernapasan yang disebabkan oleh virus dan penggunaan berlebihan antibiotik spektrum luas meningkatkan resistensi antibiotikEfek peresepan penggunaan antibiotik dalam jangka pendek pada pelayanan pengobatan dasar dapat meningkatkan kejadian resistensi.

\section{KESIMPULAN}

Berdasarkan hasil penelitian, analisis dan pembahasan maka dapat disimpulakan:

1. Pasien penderita ispa terbanyak diderita oleh wanita, usia diantara 36-45 dengan diagnosa faringitis akut

2. Hasil dari persentase menunjukkan bahwa penggunaan antibiotik untuk pasien ISPA yaitu sebesar 38,64\% melebihi angka yang telah di tetapkan yaitu $20 \%$.

3. Antibiotik paling banyak yang digunakan yaitu amoksisilin $500 \mathrm{~g}$ dengan pemberian $3 \times 1$ hari selama 5 hari.

\section{DAFTAR PUSTAKA}

Depkes RI. 2001, Direktorat Bina Farmasi Komunitas Klinik Ditjen Bina Farmasi dan Alkes, Pharmaceutical Care Untuk Penyakit Infeksi Saluran Pernafasan, 1 - 4.

Pani Sarini, Barliana MI, Halimah Eli, Pradipta IS, Annisa Nurul, 2015. Monitoring Penggunaan Antibiotik dengan Metode ATC/DDD dan DU 90\%: Studi Observasional di Seluruh Puskesmas Kabupaten Gorontalo Utara. Indonesian Journal Clinic Pharmacy.4. (4). 275-280

Neal dan Michael. J. 2006. Medical Pharmacology At Glance Edisi 5. Penerbit Erlangga: Jakarta.

Stringer dan Janet . L. 2006. Basic Concepts in Pharmacology: a Student's Survival Guide. Edisi 3. Buku Kedokteran EGC: Jakarta. Hal. 186 - 199

Pradipta IS, Febrina E, Ridwan MH, Ratnawati R, 2012. Identifikasi pola penggunaan antibiotik sebagai upaya pengendalian resistensi antibiotik.Indonesian Journal Clinic Pharmacy 1.(1):16-24.

WHO. 2016. International Statistical Classification of Diseases and Related Health Problems $10^{\text {th }}$ Revision. www.who.int

Resse R. E., Betts. R., dan Gumustop. B. 2000. Handbook of Antibiotics 3rd Ed. Lippincott Williams \& Wilkins: Philadelphia

Kermenkes, 2011. Pedoman Umum Penggunaan Antibiotik. Peraturan Menteri Kesehatan RI NOMOR 2406/MENKES/PER/XII/2011.

Kemenkes RI. 2011. Modul penggunaan Obat Rasional. Jakarta 